\title{
CHALLENGES AND ADVANCES IN THE CONSTRUCTION OF DICTIONARIES AS INSTRUMENTS FOR DISSEMINATION OF LIBRAS
}

DESAFIOS E A VANÇOS NA CONSTRUÇÃO DE DICIONÁRIOS COMO INSTRUMENTOS DE DISSIMINAÇÃO DA LIBRAS

DESAFÍOS Y AVANCES EN LA CONSTRUCCIÓN DE DICCIONARIOS

COMO INSTRUMENTOS DE DISEMINACIÓN DE LA LIBRAS

\author{
Andréa Guimarães Carvalho * \\ Messias Ramos Costa** \\ Renata Rodrigues de Oliveira Garcia***
}

\begin{abstract}
This article discusses the production of dictionaries and glossaries of Brazilian Sign Language, Libras and its main objective is to reflect and discuss the challenges and advances found in these productions over the years. The main theorists who support the reflective discussions are Faulstich (2011, 2014), Quadros and Karnopp (2004), Sofiato and Reily (2013) and Barros (2004). The research came from the research and analysis of two printed dictionaries and one virtual one. The main results were the persistence of the non-retraction / exact representation of the real dynamic three-dimensional production of the sign-term in two of these dictionaries; the lack of pertinent linguistic information that characterizes a minimum adequate structure of a dictionary, but, on the other hand, the increase of deaf and hearing researchers in the area of lexicology resulting in a growing coherent production of virtual glossaries favored by the technological advances in the present times.
\end{abstract}

Key words: Libras dictionary. Libras and lexicology. Libras glossary.

\section{Introduction}

After the recognition of Brazilian Sign Language (Libras) as a language with its own linguistic structure enjoyed by deaf subjects to interact and communicate with one another and with society, in 2002 by Lei 10.432 advances in linguistic research relating

\footnotetext{
* Mestra em Educação. Doutoranda em Linguística, PPG em Linguística, Universidade de Brasília- UnB. Professora no Curso de Letras: Libras da Universidade Federal de Goiás, UFG. E-mail: andrea.cenaudio@gmail.com.

** Mestre em Linguística. Doutorando em Linguística, PPG Universidade de Brasília. Professor no Centro Universitário de Brasília. E-mail: messias.unb13@gmail.com

*** Mestra em Ciências da Saúde. Doutoranda em Linguística, PPG Universidade de Brasília. Professora no curso de Letras: Libras da Universidade Federal de Goiás UFG. E-mail: renata20garcia@ hotmail.com
} 
to this language are being noticed, in what relates to the relationship that exists between deafness, deaf subject and Libras itself (QUADROS and KARNOPP, 2004).

This recognition has unleashed political, educational and linguistic reforms, of which we highlight the need for the spread of this language throughout the Brazilian territory associated to the structural and functional knowledge of its most rich linguistic system by society. However, together with this need, several difficulties have arisen over the years, such as: (1) absence of lexicon (signs) for specific terminologies in some areas of knowledge, involving the education of deaf people, (2) the uncontrolled momentary creation of signs-terms, between users of that language (both the deaf and hearing who are fluent in Libras), only for interactive local communication without an (in)formal linguistic preoccupation in the process of dissipation of these signs to other communities through Brazil and (3) an absence of formal and adequate linguistic instruments, validated and recognized in literature, for the teaching-learning of this language (both for the hearing as a second language - L2, and for the deaf thought in the first language $-\mathrm{L} 1)$.

However, even before this recognition as a language with its own linguistic structure, for decades Libras was gaining ground among local communities though its communicative practices between the deaf and the hearing who attended the same churches. In these religious environments it was common the informal cultivation of teaching-learning in this language to those interested.

Thinking about this historical logic, about the use and spread of Libras in distinct epochs, would the difficulties found still be the same? What strategies or formal and/or informal instruments were utilized for the concretization referring to this teaching-learning? Ultimately, what were the challenges found? And what advances have historically marked this usage, teaching-learning and dissemination described by the literature?

Despite the questions, the technological advances, articulated to the linguistic researches mentioned above, they can be seen as a probable influence in the overcoming of some of these difficulties, especially through the mediation of the creation of dictionaries and glossaries with a focus in Libras. But what can be said in reference to these "instruments" starting with the specific scientific knowledge of this area that already exist in the literature, that is, they are efficient in their organizational structure 
and completely meet the needs of its target audience? Moreover, what public would that be? And also, once taken into account the spatial-visual modality of Libras in which the tridimensional form is concretized, the existing dictionaries and glossaries can adequately meet/represent this structure without losing considerable linguistic elements?

This research paper has the general goal of describing possible challenges and advances relating to the construction of Libras dictionaries in the current days and with specific objectives: identifying and describing the existing criteria in their constitution; verifying and reporting the possible linguistic and conceptual aspects capable of functionally representing Libras for the selected target audience.

In order to do so, the structure of the article is organization as follows: an introduction presenting the problematic involved and the objectives of the article; a second item showing the theoretical framework that serves as the basis of this article; third item containing the description of the utilized methodology for the construction of this research article followed by the presenting of data and results obtained; fourth discussed item, in the form of a report, these results found under the light of the theoretical literature presented and, finally, the fifth item presenting the final considerations.

\section{Basic conceptions about dictionaries and glossaries of languages}

The dictionaries and glossaries of languages can be understood as a type of literary genre which presents, in its structures, the lexicon (words/signs) which constitute a specific language. They are generally presented in alphabetical order but, depending on the goal and way with which the language is systemically and culturally enjoyed they can, also, be organized semantically by categories.

Each lexicon can be accompanied by a conceptual term besides the complementary information that identify its value, be it grammatical, semantical, or others, such as: synonyms, grammatical class, gender, syllabic division, tonic syllable, and others.

The dictionaries are composed by one macrostructure and one microstructure. The first relates to pertinent general information, such as: title of the work, author, publisher, date, place of publication, volume(s), and epigraph. The second one, the 
microstructure, is constituted by entries, known as one word (entry) indexed in the work. "In each entry unity, the author gathers the information of grammar and lexicon that describe the entry, in such a way that the reader has, in that minimal structure, the maximum of information" 1 (FAULSTICH, 2011, p.191).

In the production of dictionaries or glossaries of a language, the information on macro and microstructure are essential, as well as the knowledge of the target audience (age group, needs, importance, and so on) before which the work is destined and its objectives. The art of production and critical study of dictionaries corresponds to the area of lexicography that, according to Biderman (2001) looks to describe the constituent lexicon of a language. In general, lexicography is defined as the scientific study of the lexicon, whose standard unity is the lexical unity (BARROS, 2004).

There are several types of dictionaries, each with its own specificity, such as: educational/scholarly ends, teaching-learning of languages, terminological guide, and so on. In general, the can be: analogical dictionaries, encyclopedic dictionaries, etymological, thematic, monolingual, bilingual, trilingual and so on. Besides, they can be printed (more conventional and they vary in thickness and size) or electronic (found in CDs/DVDs or available on the Internet). The glossaries, by their turn, can be understood as dictionaries with specific terminologies in one area and whose term, defined as a lexical unity or word, consists in its object of study (BARROS, 2004, p.40).

Barros (2004 p. 63) still adds that "the Terminology elaborates specialized vocabularies (dictionaries) and the Lexicography, dictionaries of language or specials"2. Thus, these dictionaries with specific terminologies hold technical terms in a more specific context and proper of a specific area, such as glossaries of linguistics, speech therapy, and so on, which generally are not utilized by the general public, but $b$ those who are knowledgeable or acting in a specific area. As an example, there are virtual glossaries from universities which offer the course of Letras: Libras - teacher training and translation as in the case of Universidade Federal de Santa Catarina - UFSC with specific terminology from that area.

According to Faulstich (2002) the term is described as the "word that designates the concepts of specialized area of knowledge and knowing" ${ }^{3}$. Just like the term is the standard unity in specialized dictionaries, in dictionaries and terminological glossaries for sign language, there is the sign-term. According to Faulstich (2014), sign-term is: 
1. A Term in the Brazilian Sign Language thar represents concepts with characteristics of specialized language, proper of a class of objects, of relations or of entities. 2. A Term created for, in the Brazilian Sign Language, denote concepts contained in words that are simple, composite, symbols or formulas, used in specialized fields of knowledge and knowing. 3. A Term adapted from Portuguese to represent concepts through words that are simple, composite, symbols or formulas, used in the specialized areas of the knowledge of Brazilian Sign Language ${ }^{4}$.

After several studies and research in lexicography and terminology, Faulstich presents an evaluative proportion for dictionaries of great value in the literature and which is being enjoyed as a guiding instrument for the creation of dictionaries. Such instrument will be used in this article as a basis for the analysis of the selected corpus, described in the methodology section, and of reflexive discussion about the theme discussed here.

\section{Productions of Libras dictionaries}

The production of Libras dictionaries is intrinsically articulated to the historical moments through which the deaf community has gone through amidst its fights, advances, and achievements. This takes us to an abrupt return to the past when the deaf individual was considered incapable and not-participant in society, as well as the other disabled people in society.

In the Middle Ages, the church with its monasteries, had a relevant role as a helper and those were the only places to serve as "refuge" of the people mentioned above. However, due to the search for communication/interaction with the deaf, a common language was made necessary and from them appeared the first graphic records of signs.

Sofiato and Reily (2013) mentions these first monastic manuscripts being: the Monasteriales Indicia, by the Venerable Bede, written in the 10th century; the Thesaurus Artificiosae Memoriae, by a Franciscan monk of Florence, published after his death, in 1679, and the work De Furtivis Literarum Notis, by the Italian Giovanni Battista della Porta, published in 1563, and the small work by the Spanish Franciscan monk Fray Melchior de Yeba, published posthumously. Due to the organizational structure of these manuscripts, that is, they showed an alphabet and numbers, they cannot be classified as dictionaries. 
From the religious context, the monastic signs migrated to the educational context of the deaf, but there are no records in the literature that explain such change. The first publications of a manual alphabet used in the education of the death were done by Pedro Ponce de Léon (1520-1584) in Spain, reviewed by Juan Pablo Bonet (15731633) and, after that, used by the abbot Charles Michel de L'Épée (1712-1789), in Paris. It arrived in Brazil with Ernest Huet (1858-1917), in the middle of the 19th century. In the Congress of Milan, 1880, in Italy, signaled dictionaries lose their strength with the prohibition in the use of signs in the education of the death.

As we can see, over the centuries these kinds of works were limited to monasteries, extending to decades past, but in the shape of textbooks for the teachinglearning of signs and not necessarily containing, beside the signs, concepts, grammatical descriptions, and so on.

In Brazil, the first document to appear was called Iconografia dos sinais dos surdos-mudos, in Rio de Janeiro City, 1875. Its author, Flausino da Gama, was a deaf student at the then-Imperial Instituto dos Surdos-Mudos, currently known as Instituto Nacional de Educação de Surdos (INES). In the production of that work, lithography was used (writing techniques done on limestone with the help of a fatty pencil). Threehundred eighty-two illustrated entries composed the content of that work. However, according to the authors, such work was a copy of another one, produced by the French teacher of that same Institute; his name was Pélissier (SOFIATO AND BEILY, 2013).

In 1969 the second dictionary of Libras was published in Brazil, titled Linguagem das Mãos by Eugênio Oates. Said work was influenced by the American Sign Language (ASL). After that, according to the authors mentioned above, that is, Sofiato and Reily (2013), several Libras dictionaries started to appear over the years, but three were distinguished by their influence in literature and renowned authors: Dicionário enciclopédico ilustrado trilíngue: língua de sinais brasileira (volumes I and II), by Fernando César Capovilla and Walkíria Duarte Raphael of 2001; Dicionário Digital da Língua Brasileira de Sinais 2.0 in INES (2005), whose authors are Guilherme de Azambuja Lira and Tânia Amara Felipe de Souza'; The work Livro ilustrado de língua de sinais: desvendando a comunicação usada pelas pessoas com surdez by Márcia Honora and Mary Lopes Esteves Frizanco, was published in 2009. In the first one, Sofiato and Reily mention the poor presentation of the illustrations used in 
the work, which cause, most of the time, a difficulty in the comprehension on the part of the language users and, mainly, for the first productions in sign language.

With the growing expansion of higher education in Letras: Libras, a sharp increase in the creation of dictionaries and virtual glossaries was noticed. Despite that, Sofiato and Reily (2013) highlight a preference by the users of this language for the printed form, even though they have the disadvantage of weight and thickness. Also, in 2006, another virtual production was developed: the Glossário Letras/Libras da Universidade Federal de Santa Catarina - UFSC, to help not only in the teachinglearning process of distance education, but also in the education of the deaf and the constant need for Libras interpreters ${ }^{6}$. That glossary was created in 2006 under the supervision of professor Marianne Stumpf ${ }^{7}$. Despite the expansion in the diversified creation of Libras dictionaries and glossaries, printed and virtual, and ease of access of the latter, virtual groups created in telephone applications such as WhatsApp and Telegram containing professionals from Libras (teachers and interpreters), have also shown themselves to be effective in the exchange of experiences for regional signs and in detailed linguistic discussions in the creation of new words in Libras.

Thus, the advances concerning the production of dictionaries or other material, for similar purposes, and the influences and environmental, policies, educational and technological conditions in the creation of these are remarkable. Despite that, it is necessary to investigate in greater depth their efficacies relating to the objectives for which they were created and, mainly, to the target-audience for which they were created.

\section{Methodology}

To fulfill the proposed objectives of the research we utilized the methodology of qualitative approach. According to Bogdan and Biklen (1994, p.16) the questions formulated in a qualitative research have the objective of investigating phenomena in all their complexity and in a natural context, "the researcher introduces himself to the world of the people he intends to study, tries to know them, to make himself known and to win their confidence, developing, whenever possible, a written and systematic record of everything he reads, hears and observes ${ }^{8}$. Therefore, the qualitative work becomes 
somewhat descriptive, valuing the perspectives of the participants involved, the contextual interrelations, the analysis of material produced in a natural environment.

In addition, it is observed how and under which circumstances this material was elaborated, with the aim of revealing the multiple meanings of a situation or a linguistic phenomenon, being a concern with the conditions of production of the research and with a wider and more significant social environment. Harré and R. Gillet (1999, p.25) add that:

[...] the experimenter or observer must enter into a discourse with the people being studied and try to appreciate the contours of the subject's cognitive world. However, at this point, it does not make sense at all to talk about observers and participants. There are only co-participants in the project to draw a sense of the world and what we live in it ${ }^{9}$.

The ideas of the authors mentioned motivates us to understand the discourse of the participants immersed in one time, one space, one sociocultural environmental and one body, what they thought/reflected upon, the sense they gave the situations of life while in the usage of language. For Minayo and Sanches (1993):

[...] the qualitative work always walks in two directions: in one, it elaborates its theories, its methods, its principles and establishes its results; in another, it invents, ratifies its way, abandons certain alleys and takes privileged directions $[\ldots]$ shares the idea of 'becoming' in the concept of scientificity ${ }^{10}$.

Even though qualitative research presents a delimited theoretical framework, clear research objectives and principles underlying the construction of scientific knowledge, it allows the use of different instruments and changes in the course, when the field research and the context of the research require - in this sense, the researcher becomes the main instrument; there is a tendency to description; more interest in the processes than in the results or products; Inductive data analysis; focus on meaning. Also, the analytical process is interpretive and, based on the specificities of the context, the research judgment is based on the description of the data obtained by the researcher. This becomes pertinent for the analysis of the internal complexity of the linguistic category that one intends to investigate to the cultural diversity in which it is inserted, to the historical and to the social of the populations involved.

The instruments utilized in the research were: a virtual, public access dictionary known as: Dicionário Digital da Língua Brasileira de Sinais - Ines, from Rio de 
Janeiro $^{11}$, produced and published in 2005, and two printed dictionaries, that is, one with the name Mini dicionário Ilustrado de Libras - SAT Serviço de Ajudas Técnicas do Rio Grande do Sul ${ }^{12}$, produced and available in 2010 and the other dictionary is a book under the name Dicionário Ilustrado de Libras Língua Brasileira de Sinais by author Flávia Brandão, edited in 2011.

The choice of the dictionaries occurred thinking of a contrastive perspective between data obtained from printed and virtual dictionaries, more recent, arranged in the literature and easily accessible to the public, speakers of Libras or learners of that language. From this contrast lay out the results obtained in order to allow the reader to draw a comparative profile with the first dictionaries that have been produced and presented in the literature to date and which were previously discussed in the theoretical development of this article

Thus, in the first moment a theoretical survey was carried out on the topic of the research, discussed in this article, available in the current literature. This survey allowed updating and complementing relevant knowledge for a later reflective collective discussion and that was prepared at the end of the article.

In the second moment a detailed observation of the linguistic structure of the three (3) dictionaries was made, separately, from which important data about its contents were extracted. These data were drawn from the questionnaire model (attached) produced specially for their analysis, created by the author Faulstich (2014).

In the third moment, after the data collection in the questionnaire, there was an objective description of the results obtained from the data and that, later, were analyzed in light of the theory studied.

In the fourth moment, after analysis, a relevant reflective discussion ensued, generating a descriptive report presenting the conclusions and/or final considerations obtained from the knowledge acquired with the investigations/researches made, allowing for new insights on the topic of article research in question.

\section{Results and discussions}

About the virtual dictionary Dicionário Digital da Língua Brasileira de SinaisInes, from Rio de Janeiro, it was possible to realize that that is a bilingual digital 
dictionary because it presents signs of Brazilian Sign Language (Libras), illustrated in images, and conceptual writing of said signs in the Portuguese Language (LP).

We noticed that this work, that is, this dictionary, differs from digital dictionaries of oral languages where, generally, we find conceptual descriptions, synonymies, grammatical class in which the word-term refers to itself, and so on. The Libras virtual dictionary, on the other hand, shows LP digital vocabularies as words, meanings, subjects, grammatical classes, origins and also shows the videos in Libras, researched by the authors themselves, teachers from Rio de Janeiro with an education in Art. It is interesting that, since that was a local work, it tends to present local regional signs, that are not always used in other regions like Goiás, Distrito Federal and others, as shown in the figure below.

Figure 1: Dicionário Digital de Língua Brasileira de Sinais - INES

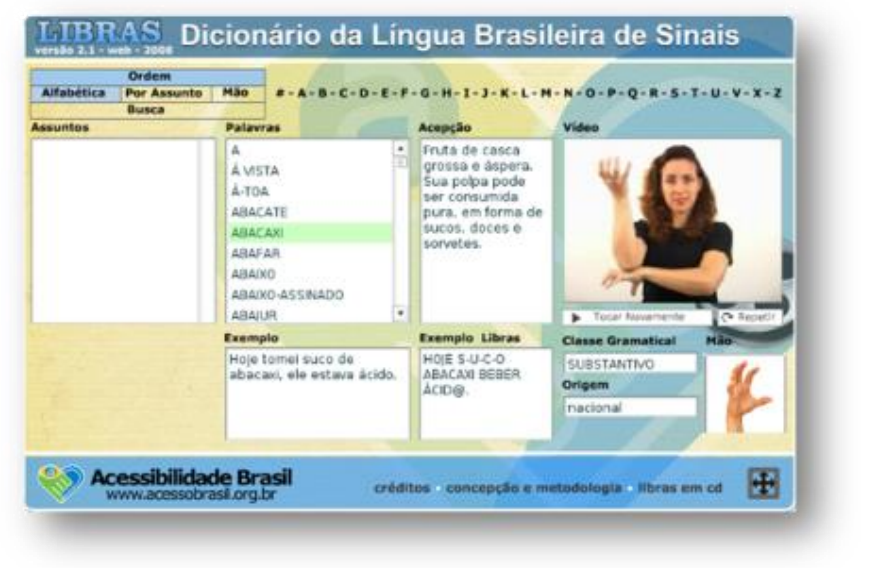

Source: INES (2005).

Therefore, for example, if a learner or speaker of Libras wants to refer to the sign for 'ABACAXI' (pineapple) in the virtual dictionary, they will find a quadrant containing the video illustrating how the sign is produced; another quadrant showing a phrasal example of how it can be used when contextualized in a sentence in LP and another quadrant containing a sentence contextualized in Libras; origin of the sign; grammar class to which it belongs; meaning and hand configuration used in the sign production.

Using the inventory of bilingual digital dictionaries we did, we must compare between the printed dictionary and the digital dictionary using the Libras/LP through 
some techniques or scientific. The works of local dictionaries show signs used by Libras speakers in the local region only, and generally do not show the probable linguistic variations of other regional ones. This sampling of variations is necessary because some Brazilian listeners do not know signs by the deaf community of the city of Rio de Janeiro and can be confused using it in the wrong way in the wrong place, triggering misinterpretation and communicative interaction.

The works presented the signs with the possible uses of meanings so that we should learn the signs in context. The dictionary organization represents the entries that have already created sentences in Portuguese and Libras to exemplify the signs in context. The example should use the signals in appropriate contexts, helping to identify the meaning. For many entries the example in Portuguese corresponds to the example in Libras because they are two languages: Libras and LP.

We noticed that the bilingual digital dictionary must modify a bit more because the hearing Brazilian people utilize the digital bilingual dictionary and must be confused when learning signs without the context of conversation.

The printed dictionary Dicionário ilustrado de LIBRAS Língua Brasileira de Sinais by Flávia Brandão, produced and edited in 2011 has 3,212 signs-terms followed by their meaning in written Portuguese and the detailed explanation for how the signs are executed, as per Image 2 below.

Figure 2 - Dicionário Ilustrado de LIBRAS: Língua Brasileira de Sinais, by Brandão.
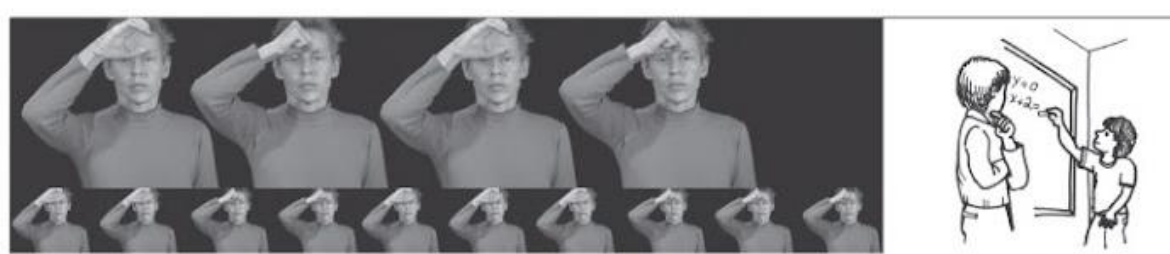

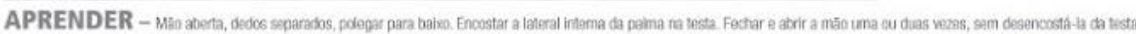

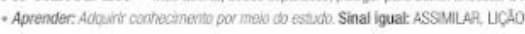

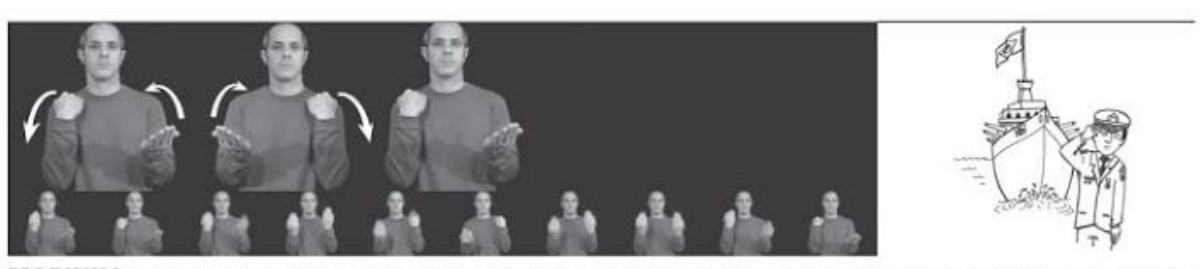

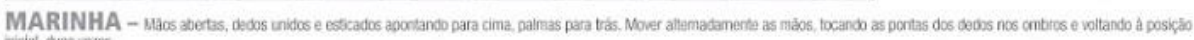

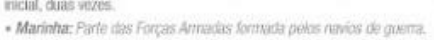

Source: BRANDÃO (2011, p.13). 
Figure 2 shows the signs "APRENDER" and the sign "MARINHA". We can observe a visual preoccupation in showing, step-by-step, how signals are produced from a sequential cut of photographic images. Beside it, there is a quadrant containing an example of another image, that is, a contextualized drawing referring to the signal and the LP entry that appears just below the two images.

It is interesting that in the part written in LP, there is only a brief concept, even disposed in a smaller (almost imperceptible) font than would be the term, but there is no grammatical class layout to which they belong and no other pertinent information. There is also, in front of the entry, a description, in LP, of how the signal is produced.

In the dictionary's book a brief description of some items was found, such as: personal file of the author, with a background in Art; goal of the dictionary that, according to the author, is aimed at disseminating the meanings of the signs that make up Libras and the way they are executed; adults as a target audience. There is no clear description of how the dictionary can be used. Therefore, an insufficiency of data is perceived, both in the macrostructure and microstructure that would characterize and validate it as a dictionary according to the current literature regarding the field of Lexicology.

The same can also be said of the other printed dictionary, the Mini dicionário ilustrado de Libras - SAT Serviço de Ajudas Técnicas from Rio Grande do Sul ${ }^{13}$ and produced in 2010. As per the image below, we can see an insufficiency of data both in the macro and microstructure of a dictionary.

Figure 3 - Mini dicionário ilustrado de Libras: SAT Serviço de Ajudas Técnicas.
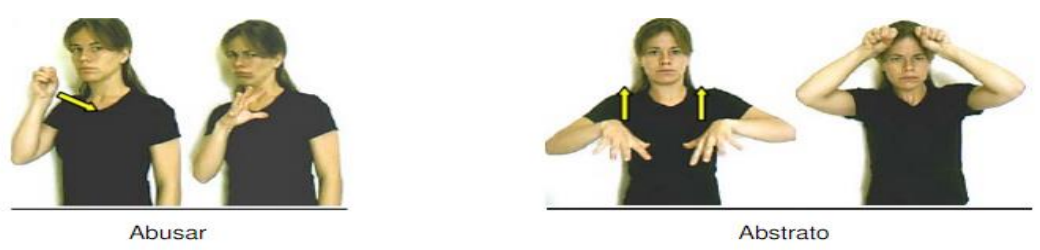

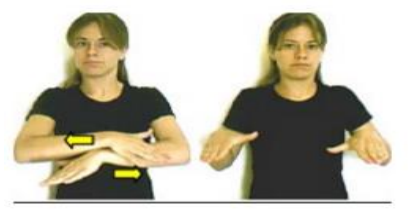

Acabar

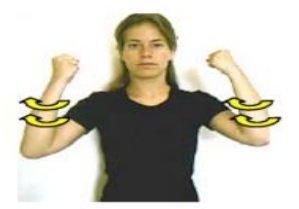

Academia

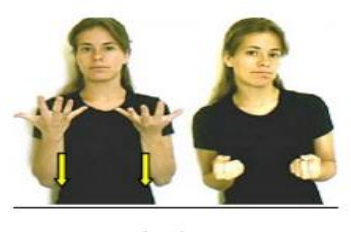

Aceitar

Source: CLÁUDIO et al. (2010, p.13). 
Figure 3 shows an even greater insufficiency of data showing only the nonsequential photographic image of how the signals are executed in isolation, with no concern for a more contextualized signal presentation. The idea conveyed is that it is a textbook used by language learners. However, the non-contextualization of the signals can generate a confusion of how and when to use them properly. Moreover, the conceptual absence of entries further aggravates the picture presented.

\section{Final thoughts}

From the analysis of the results obtained, in the light of the studied theory, it is possible to report that, referring to the construction of Libras dictionaries in the present day, some authors still persist with focus in the visual presentation of the execution of the term signs, in dictionaries printed as virtual. This is likely to occur because the differentiated mode of sign language is spatial-visual.

However, one of the major challenges in these presentations is the exact retraction/representation of the actual three-dimensional dynamic production of the signal-term when exposed in these dictionaries. Also, when this presentation is shown in the form of videos in the virtual dictionaries, they are clearer for apprentices and consultants of Libras (interpreters of Libras, deaf instructors, and so on.). In printed dictionaries, the sequential presentation of the signs in photos can lead to errors and/or doubts in the correct execution of the signs, not being a good option for queries, depending on the purpose for which this dictionary is intended.

In addition, the lack of complementary information such as: the non-placement of concepts or meanings, synonyms, grammatical class to which they belong and contextualized examples of these signs that would demarcate a characteristic structure of a dictionary reduce its linguistic functionality, that is, deprive its users of important information regarding the understanding of the lexicon of the language and even, because of this, limit the target audience for which the dictionary was intended.

On the one hand, if there is still a "visual tradition" in the production of these dictionaries, not always beneficial to users and learners of the language, on the other, with the technological advances, there is an increase and efficiency in the production of dictionaries and virtual glossaries of Libras, with more specific terminology (by area), plus linguistic information more pertinent to these users and learners facilitating not 
only their rapid access to this information but the dissipation of them beyond the regional borders allowing the rapid exchange of knowledge about this language.

One can say that this advance, associated with technological modernity, has also occurred thanks to the increase in the demand and access of listeners and, especially, deaf people in the area of research related to lexicology. These advances have enriched, motivated and contributed to deeper studies in the area of local signal language linguistics.

\section{Resumo}

Este artigo discorre sobre a produção de dicionários e glossários de Língua Brasileira de Sinais (Libras), com o objetivo de trazer algumas reflexões sobre o crescimento, nos últimos anos, desse tipo de publicação, tendo como principais teóricos a sustentar as discussões reflexivas: Faulstich, Quadros, Karnopp, Sofiato, Reily e Barros. Este trabalho, que resulta da análise de dois dicionários impressos e um virtual, teve como principal decorrência a verificação, em dois desses dicionários, da persistência da não retratação/representação exata da produção dinâmica real, tridimensional, do sinaltermo. E ainda, a constatação da falta de informações linguísticas pertinentes, que caracterizam um dicionário. Essas publicações, no entanto, têm promovido um aumento na atividade de pesquisadores surdos e ouvintes na área de lexicologia e uma crescente produção de glossários virtuais, favorecidos pelos avanços tecnológicos.

Palavras-chave: Dicionários de Libras. Libras e Lexicologia. Glossários de Libras.

\section{Resumen}

Este artículo se ocupa de la producción de diccionarios y glosarios en Lengua Brasileña de Señales, Libras, y tiene como objetivo principal traer algunas reflexiones sobre los desafíos y los avances de esas producciones a lo largo de los últimos años. Los principales teóricos que sostienen las discusiones reflexivas son Faulstich, Quadros, Karnopp, Sofiato, Reily y Barros. Esta investigación ocurrió a partir de la investigación y análisis de dos diccionarios impresos y un virtual. Se tuvo como principales resultados la verificación: de la persistencia de la no retractación / representación exacta de la producción dinámica real tridimensional del signo-término en dos de esos diccionarios; de la falta de información lingüística pertinente, que caracterizan una estructura adecuada mínima de un diccionario, pero, en contrapartida, el aumento de investigadores sordos y oyentes en el área de lexicología, resultando en una creciente producción coherente de glosarios virtuales favorecidos por los avances tecnológicos en los tiempos actuales.

Palabras clave: Diccionarios de Libras. Libras y producción de diccionarios. Glosarios de Libras. 


\section{References}

BARROS, L. A. Curso Básico de Terminologia. São Paulo: Editora da Universidade de São Paulo, 2004.

BIDERMAN, M. T. C., Terminologia e Lexicografia. In: Trad Term, 7, 2001, p. 153181, Universidade Estadual Paulista (UNESP), Brasil. Disponível em: <http://www.revistas.usp.br/tradterm/article/view/49147> Acesso em: 30 out. 2016.

BOGDAN, R.C.; BIKLEN, S. K. Investigação qualitativa em educação. Trad. Maria João Alvarez, Sara Bahia dos Santos and Telmo Mourinho Baptista. Porto: Porto Editora, 1994.

BRANDÃO, F. Dicionário Ilustrado de LIBRAS Língua Brasileira de Sinais. São Paulo: Global, 2011.

BRASIL. Lei $\mathrm{n}^{\circ}$ 10.436, de 24 de abril de 2002. Dispõe sobre a Língua Brasileira de Sinais - Libras e dá outras providências. Brasília, DF, abr. 2002. Disponível em: http://www.planalto.gov.br/ccivil_03/leis/2002/L10436.htm. Acesso em: 10 abr. 2018.

Decreto $\mathrm{n}^{\circ}$ 5.626, de 22 de dezembro de 2005. Regulamenta a Lei $\mathbf{n}^{\circ}$

10.436, de 24 de abril de 2002, que dispõe sobre a Língua Brasileira de Sinais Libras. Brasília, DF, dez. 2005. Disponível em:

http://www.planalto.gov.br/ccivil_03/_ato20042006/2005/decreto /d5626.htm Acesso em: 10 jun. 2017.

CAPOVILLA, F. C.; RAPHAEL, W. D. Dicionário enciclopédico ilustrado trilíngue: língua de sinais Brasileira (vol. I and II). $3^{\mathrm{a}}$ ed. São Paulo: Edusp, Fapesp, Fundação Vitae, Feneis, Brasil Telecom, 2001.

CLÁUdiO, J. P.; ABREU, L. S.; RODRIGUES, P. S. et al. SAT Serviço de Ajudas Técnicas Mini dicionário. CAS/RS. Fundação de Articulação de políticas públicas para pessoas com deficiência e altas habilidades do Rio Grande do Sul - FADERS. Porto Alegre, 2010. Disponível em:

http://www.faders.rs.gov.br/uploads/Dicionario_Libras_CAS_FADERS1.pdf. Acesso em: 6 out. 2016

FAULSTICH, E. Base metodológica para pesquisa em socioterminologia. Termo e Variação. Brasília: UnB, 1995.

Para gostar de ler um dicionário. In: RAMOS, C. M. A; BEZERRA, J. R. M; ROCHA, M. F. S (Org). Pelos caminhos da Dialetologia e da Sociolinguística: entrelaçando saberes e vidas - homenagem a Socorro Aragão. São Luís: EDUFMA, 2002.

Avaliação de dicionários: uma proposta metodológica, Organon, Porto

Alegre, $\mathrm{n}^{\mathrm{o}}$ 50, janeiro-junho, 2011. p. 181-220. Disponível em: http://seer.ufrgs.br/index.php/organon/article/view/28346/16994. Acesso em: 2 jun 2016. 
FAULSTICH, E.; ABREU, S.P. (Orgs.) Linguística aplicada à terminologia e a lexicologia. Porto Alegre: UFRGS, 2014.

HARRÉ, R. \& GILLET, G. A mente discursiva: os avanços na ciência cognitiva. Trad. Batista D. Porto Alegre: Artmed, 1999.

HONORA, M.; FRIZANCO, M.L.E. Livro Ilustrado de Língua Brasileira de Sinais: desvendando a comunicação usada por pessoas com surdez. São Paulo: Ciranda Cultural, 2009.

LIRA, G. A; SOUZA, T.F.. Dicionário Digital da Língua Brasileira de Sinais (INES/RJ). Rio de Janeiro: Instituto Nacional de Educação dos Surdos - INES, 2005.

MINAYO, M. C. S.; SANCHES, O. Quantitativo-qualitativo: oposição ou complementaridade. Cad. Saúde Pública, Rio de janeiro, v.9, n.3,p.239-262, jul./set., 1993.

QUADROS, R.M.; KARNOPP, L. Língua de Sinais Brasileira: estudos linguísticos. Porto Alegre: ArtMed, 2004.

STUMPF, M. R. Desenvolvimento de glossários de Sinais Acadêmicos em ambiente virtual de aprendizagem do curso Letras-Libras. Informática na Educação: teoria e prática - Porto Alegre, v. 16, n.2, jul/dez. 2006.

SOFIATO, C. G., REILY, L. Dicionários e manuais de língua de sinais - análise crítica das imagens pp. 149 - 160 in LACERDA, C. B. F., SANTOS, L. F. (Org.), Tenho um aluno surdo, e agora? Introdução à Libras e educação de surdos. São Carlos: EdUFSCAR, 2013.

Dicionarização da língua brasileira de sinais: estudo comparativo iconográfico e lexical, Educação e Pesquisa, vol. 40, num. 1. São Paulo: Universidade de São Paulo-USP, 2014, PP. 109-126. Disponível em: http://www.revistas.usp.br/ep/article/view/81881 Acesso em: 16 mai 2016.

UMIKER-SEBEOK, J.; SEBEOK, T.A. (Orgs.). Monastic sign languages. Nova York: Mouton de Gruyter, 1987.

\section{Notes}

\footnotetext{
${ }^{1}$ Em cada unidade de verbete, o autor reúne as informações de gramática e de léxico que descrevem a entrada, de forma que o leitor tenha, naquela estrutura mínima, o máximo de informação.

${ }^{2}$ [...] a Terminologia elabora vocabulários (dicionários) especializados e a Lexicografia, dicionários de língua ou especiais.

${ }^{3}[\ldots]$ palavra que designa os conceitos de área especializada do conhecimento e do saber.

4 1- Termo da Língua Brasileira de Sinais que representa conceitos com características de linguagem especializada, próprias de classe de objetos, de relações ou de entidades. 2- Termo criado para na Língua de Sinais Brasileira, denotar conceitos contidos nas palavras simples, compostas, símbolos ou fórmulas,
} 
usados nas áreas especializadas do conhecimento e do saber. 3- Termo adaptado do português para representar conceitos por meio de palavras simples, compostas, símbolos ou fórmulas, usados nas áreas especializadas do conhecimento da Língua de Sinais Brasileira.

${ }^{5}$ That dictionary is available at < http://www.ines.gov.br/dicionario-de-libras/main site/libras.htm $>$ and was created in 2005 ;

${ }^{6}$ That glossary was created in 2006 under the supervision of professor Marianne Stumpf and is available at < http://glossario.libras.ufsc.br/letraslibras $>$.

${ }^{7}$ Available at < http://glossario.libras.ufsc.br/letraslibras $>$.

${ }^{8}$ [...] o investigador introduz-se no mundo das pessoas que pretende estudar, tenta conhecê-las, dar-se a conhecer e ganhar a sua confiança, elaborando, quando possível, um registro escrito e sistemático de tudo aquilo que lê, ouve e observa.

${ }^{9}[. .$.$] é necessário entrar no discurso junto às pessoas que estão sendo estudadas e tentar apreciar os$ contornos do mundo cognitivo do sujeito. No entanto, não há sentido em falar sobre observadores e participantes. Há apenas co-participantes para extrair um senso do mundo e do que vivemos nele

${ }^{10}[\ldots]$ o trabalho qualitativo caminha sempre em duas direções: numa, elabora suas teorias, seus métodos, seus princípios e estabelece seus resultados; noutra, inventa, ratifica seu caminho, abandona certas vias e toma direções privilegiadas [...] compartilha a ideia de 'devir' no conceito de cientificidade.

11 Available at <www.ines.gov.br/dicionario-de-libras/>

12 Available at: http://www.faders.rs.gov.br/uploads/Dicionario Libras_CAS_FADERS1.pdf>

13 Available at < http://www.faders.rs.gov.br/uploads/Dicionario_Libras_CAS_FADERS1.pdf $>$ 